\title{
Magnetostratigraphy and Tectonic Rotation of the Eocene-Oligocene Makah and Hoko River Formations, Northwest Washington, USA
}

\author{
Donald R. Prothero, ${ }^{1}$ Elizabeth Draus, ${ }^{1}$ and Casey Burns ${ }^{2}$ \\ ${ }^{1}$ Department of Geology, Occidental College, Los Angeles, CA 90041, USA \\ ${ }^{2}$ Burke Memorial Museum, University of Washington, P.O. Box 353010, Seattle, WA 98195, USA \\ Correspondence should be addressed to Donald R. Prothero, prothero@oxy.edu
}

Received 14 August 2008; Revised 19 December 2008; Accepted 17 March 2009

Recommended by Rudolf A. Treumann

The Eocene-Oligocene Makah Formation and subjacent middle Eocene Hoko River Formation of the northwestern Olympic Peninsula, Washington, yield mollusks, crustaceans, foraminifera, and early neocete whales; their age has never been precisely established. We sampled several sections; most samples showed a stable single-component remanence held largely in magnetite and passed a Class I reversal test. The upper Refugian (late Eocene) and lower Zemorrian (early Oligocene) rocks at Baada Point correlate with Chron C13r (33.7-34.7 Ma) and Chron C12r (30-33 Ma). The Ozette Highway section of the Makah Formation spanned the early Refugian to late Refugian, with a sequence that correlates with Chrons C15r-C13r (33.7-35.3 Ma), and a long reversed early Zemorrian section that correlates with Chron C12r (30-33 Ma). The type section of the Hoko River Formation correlates with Chron C18r (40.0-41.2 Ma). The area sampled shows about $45^{\circ}$ of post-Oligocene counterclockwise tectonic rotation, consistent with results obtained from the Eocene-Oligocene rocks in the region.

Copyright (c) 2009 Donald R. Prothero et al. This is an open access article distributed under the Creative Commons Attribution License, which permits unrestricted use, distribution, and reproduction in any medium, provided the original work is properly cited.

\section{Introduction}

During the Eocene-Oligocene transition (from about 40 to $30 \mathrm{Ma})$, the Earth went through a dramatic transformation, with the "greenhouse" conditions of the early Eocene being replaced by the "icehouse" conditions of the Oligocene [15]. Antarctic glaciers appeared for the first time since the Permian, and cold Antarctic bottom waters were formed, beginning the modern pattern of oceanic circulation $[1,6]$. Several episodes of mass extinction occurred through this interval, especially at the end of the middle Eocene (37 Ma), and in the earliest Oligocene (33 Ma), primarily in response to pulses of global cooling. Several extraterrestrial objects struck the Earth as well, but these impacts all occurred during the middle of the late Eocene (most of them are dated at $35.5-36.0 \mathrm{Ma}$ ) and are associated with no extinctions of consequence [7].

In recent years, our understanding of the EoceneOligocene transition has greatly improved. Several deep marine sections and ocean cores have been recovered from around the world, and these have allowed a detailed examination of the paleoceanographic, stable isotopic, and micropaleontologic changes at high resolution $[1,2,5]$. Much of the information for the global marine record was summarized in Berggren and Prothero [2] and Prothero, Ivany, and Nesbitt [5]. In addition, some shallow marine sequences, such as those in the Gulf Coast, have been analyzed in detail, allowing studies of the biotic changes in the benthic foraminifera [9], mollusks [10, 11], echinoids [12], and pollen [13]. The terrestrial record in North America has also been calibrated by magnetic stratigraphy, and the systematics and biostratigraphy of the terrestrial organisms have recently been summarized [2-4, 14].

Compared with all these recent researchs, our understanding of the rich fossil record of the marine EoceneOligocene in the Pacific Coast has lagged behind. Since the beginning of this century, the biostratigraphy of these 


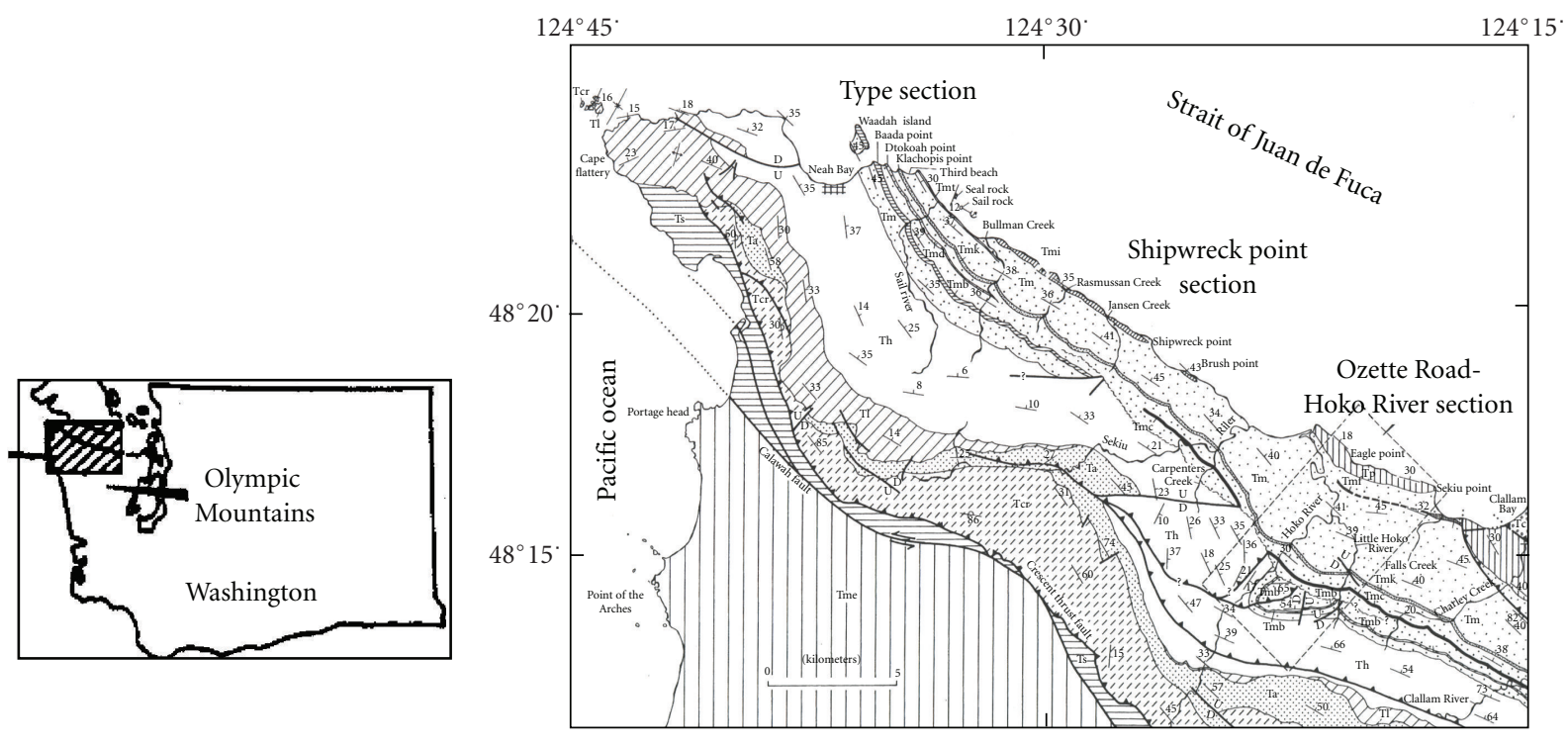

(a)

(b)

Figure 1: (A) Index map showing location of study in the northwest Olympic Peninsula. Modified from Snavely et al. [8, Figure 1]. (b) Geologic map of the northwest Olympic Peninsula, showing the location of the sections mentioned in this paper. Stippled outcrop pattern $(\mathrm{Tm})$ indicates the Makah Formation, and its various named members ( Tmb = Baada Point Member; Tmd = Dtokoah Point Member; Tmc = Carpenters Creek Member; Tmk = Klachopis Creek Member; Tmj = Jansen Creek Member). Unshaded outcrop = Hoko River Formation (Th symbols). Other formations: Tc = Clallam Formation (open circle pattern); Tp = Pysht Formation (vertical line pattern); $\mathrm{Tl}=\mathrm{Lyre}$ River Formation (diagonal line pattern); $\mathrm{Ta}=$ Aldwell Formation (fine stipple pattern); Tme = mélange (wide vertical line pattern); Ts = lower sandstone and siltstone (horizontal line pattern); Tcr = Crescent Formation (basal volcanic unit). Modified from Snavely et al. [8, Figure 2].

strata has been based primarily on the abundant benthic organisms because planktonic microfossils are scarce in these mostly shallow-water deposits. Mollusks have long been used, but their biostratigraphic zones are very long and thus low in resolution. For example, the middle-late Eoceneearly Oligocene "Tejon" molluscan stage spans almost the entire Eocene-Oligocene transition, or about 10 million years in duration (from about $34-44 \mathrm{Ma}$ ), and the other molluscan stages of the Eocene and Oligocene are almost as long [15].

Benthic foraminifera are the most abundant and widespread fossils in these strata, so they have been used for most biostratigraphic studies in the Pacific Coast. However, many of the benthic foraminiferal zones are also very long and low in resolution. For example, the middle Eocene Narizian stage spans about 8 million years (39-48 Ma), the late Eocene Refugian stage spans about 7 million years $(39-32 \mathrm{Ma})$, and the Zemorrian stage spans most of the Oligocene [15]. In addition, benthic foraminifera also track paleobathymetric changes, and so some of the zonations based on benthic foraminifera have proven to be timetransgressive, especially between California and Washington $[15,16]$.

Where planktonic microfossils are available, they have greatly improved the correlation with the global time scale (see papers summarized in [15]). However, the majority of these Pacific Coast sections yield few or no planktonic microfossils, usually, because they were deposited in shallow marine conditions, or have undergone too much dissolution and diagenesis.
When the available biostratigraphic data are combined with magnetic stratigraphy, much higher resolution is possible as well as precise (to the nearest 100000 years) correlation with the global time scale. For example, Prothero and Armentrout [17] used calcareous nannoplankton to calibrate their magnetic stratigraphy and were able to date the upper Eocene-Oligocene Lincoln Creek Formation in the southern Olympic Peninsula of Washington. This study showed that the Refugian stage as recognized in Washington by Rau $[18,19]$ is both late Eocene and early Oligocene in age (magnetic Chrons C15rC12r, about 33-35 Ma). The type area of the Refugian stage in the western Santa Ynez Range, Santa Barbara County, California, is mostly late Eocene but also earliest Oligocene (magnetic Chrons C13n-C12r, about 34.5$33.5 \mathrm{Ma}$ ) [20].

Finally, the Eocene-Oligocene transition is an important period of earth history because it marks the origination of both major living groups of whales, the baleen-bearing mysticetes, and the toothed odontocetes [21]. Although it is possible that the earliest mysticete comes from the late Eocene of New Zealand and Seymour Island, Antarctica, the oldest odontocete so far reported comes from the lower Oligocene part of the Makah Formation in Washington [21-23]. The lower Makah also yields specimens of some of the most primitive mysticetes, which bear both teeth and the insertion areas for baleen as well. Thus, precise dating of these marine beds of the northwest Olympic Peninsula is critical to our understanding of whale evolution. 


\section{Geologic Setting}

The Makah and Hoko River Formations are an important deep-marine record of the Eocene and Oligocene exposed to low-tide beaches, sea cliffs, creeks, and roadcuts on the northwestern corner of the Olympic Peninsula (Figures 1 and 2). They crop out in a northward-dipping homoclinal sequence along the northwestern coast of the Olympic Peninsula, part of almost $6000 \mathrm{~m}$ of Eocene to Miocene marine sediments. The entire sedimentary sequence unconformably overlies pillow basalts and breccias of the Crescent volcanics, which were exotic oceanic ridge and seamount terranes that accreted to North America in the early Eocene [2426]. The Makah Formation is conformably overlain by the Oligocene Pysht Formation, which is better exposed in the north-central coast of the Olympic Peninsula between Clallam Bay and Lyre River [27] to the east of our study area.

Not only is the Makah Formation fossiliferous with mollusks $[8,28]$, crustaceans $[8,29-35]$, and benthic foraminifera [8], but it also yields it also yields birds [36], terrestrial plants [37-39], and some of the earliest known fossils of baleen and toothed whales [23]. Some of these fossils come from apparent chemosymbiotic communities [40-42], including communities that are apparently associated with decaying whale carcasses and sunken wood [22, 43-45].

The rocks in the area were originally mapped as part of the Twin River Formation [46-49]. Snavely et al. [24] raised the Twin River Formation to group rank and subdivided it into three new formations: Hoko River, Makah, and Pysht. Snavely et al. [28] further subdivided the Makah Formation into members named (from lowest to highest): the Baada Point, Dtokoah Point, Klachopis Point, Third Beach, and Jansen Creek Members, with marker beds such as the Carpenter Creek Tuff member serving as dividing points. Snavely et al. [24] designated the type section of the Makah Formation as the wave-cut beaches along the Straits of Juan de Fuca from Waadah Island and Baada Point to Kydaka Point. Rocks along the Sekiu and Hoko rivers were selected as reference sections.

Most of the Makah Formation consists of deep-water siltstones and thick turbidite sandstones, with occasional conglomerates. The uppermost unit, the Jansen Creek Member, is bathyal as well, Snavely et al. [28] interpreted some of the Jansen Creek Member as shallow-marine deposits. Snavely et al. [28] pointed out that there are many olistostromes in the Jansen Creek Member, and there are also sandstones containing bathyal turrids and other mollusks (C. Hickman, written comm.) as well as numerous cold seeps (J. Goedert, pers. comm.). The Jansen Creek Member is the most fossiliferous unit in the Makah Formation.

In some places the cumulative thickness of the Makah Formation is estimated to be about $2800 \mathrm{~m}$, but most surface sections are much less thick and complete than this. The Makah Formation yields Refugian (late Eocene) benthic foraminifera in the lower part and Zemorrian (Oligocene) foraminifera in the upper half.

The Hoko River Formation was named by Snavely et al.[24] for a deep marine sequence of siltstones and lesser

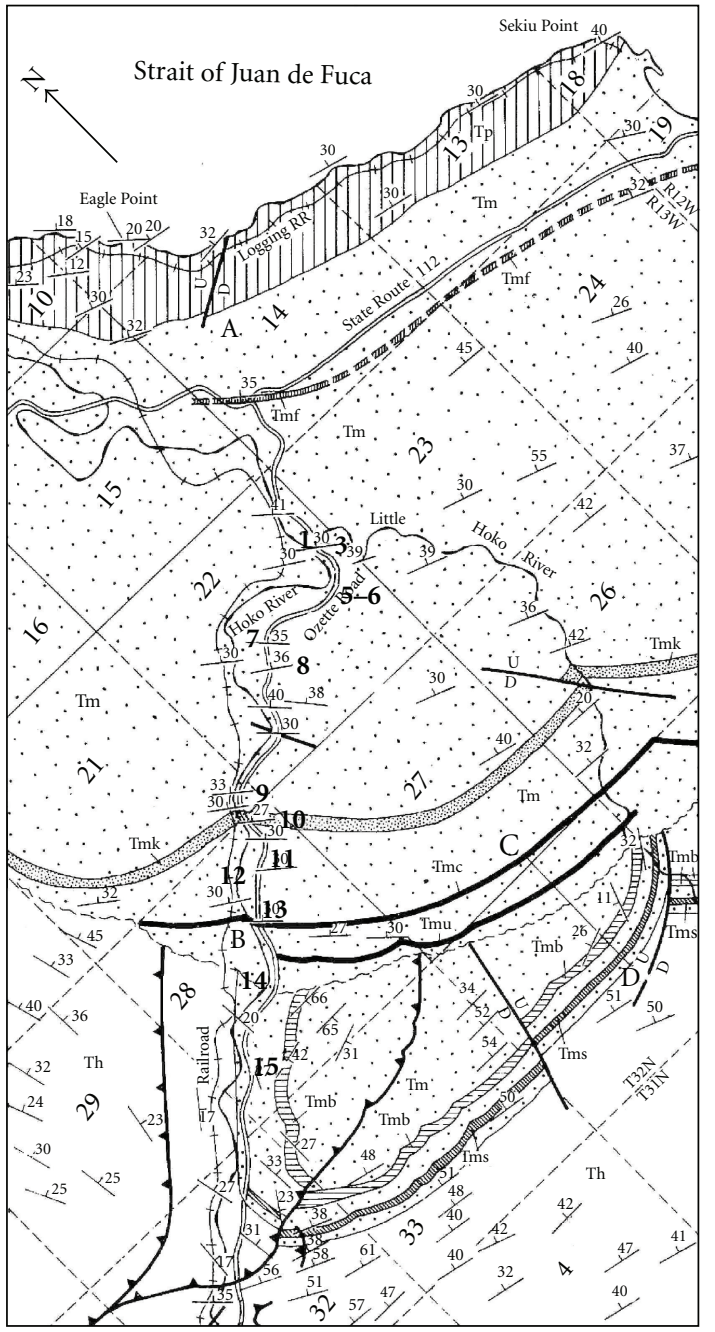

Figure 2: Index map showing location of sampling sites (bold numbers) along Ozette Road and the Hoko River. Formation abbreviations as in Figure 1(a). Modified from Snavely et al. [8, Figure 3].

sandstones exposed beneath and to the south of the main belt of Makah exposures (Figure 1). In some places, there are channels and lenses of conglomerate and lithic sandstone in the formation, filled with clasts of basalt, phyllite, and metaigneous rocks; these clasts occasionally reach 3-5.6 m in diameter. Calcareous concretions in the formation yield fossil crabs [30, 46-50], gastropods, cephalopods [51], and carbonized wood. The type section is about $1600 \mathrm{~m}$ thick, although exposures are poor in most places, even in the best outcrops along the Ozette Highway and Hoko River (Figure 2). However, Snavely et al. [24, page A115] report up to $2300 \mathrm{~m}$ of section in the reference section at Deep Creek. A major unconformity separates the Hoko River Formation from the overlying Makah Formation. The Lyre Formation conformably underlies the Hoko River Formation in some places, but intertongues with the Hoko River Formation in others. 


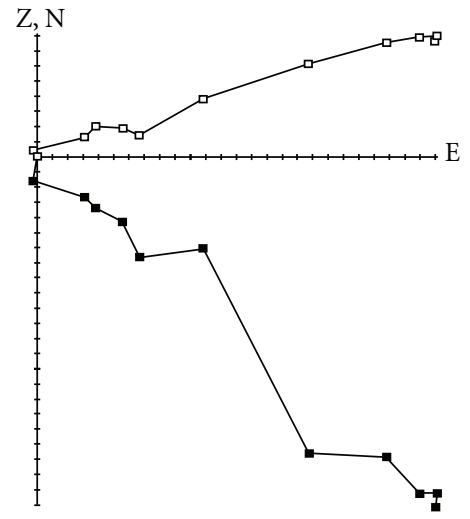

(a)

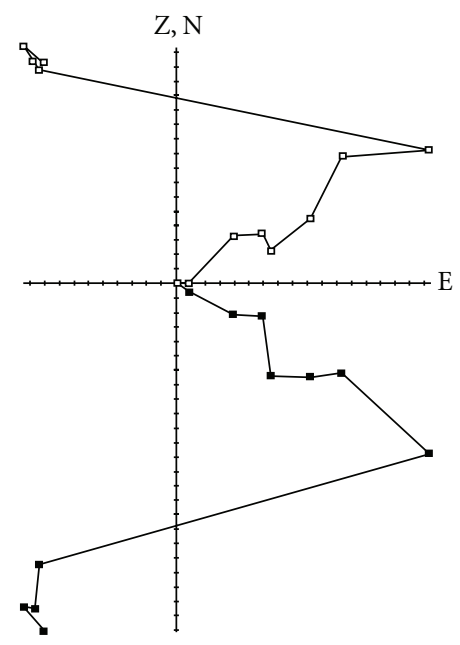

(d)

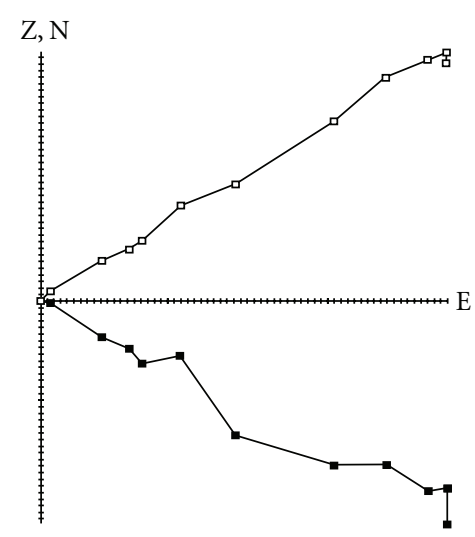

(b)

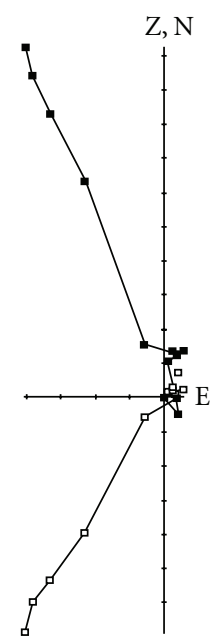

(e)

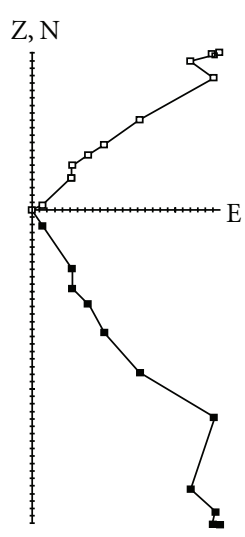

(c)

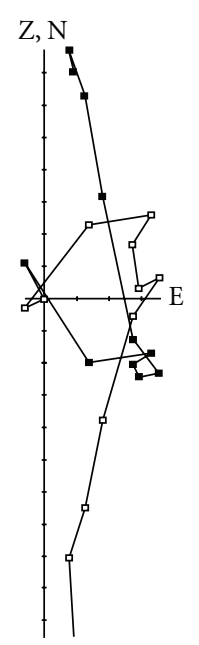

(f)

FIGURE 3: Orthogonal demagnetization (“Zijderveld”) plots of representative samples after dip correction (stratigraphic coordinates). Solid squares indicate declination (horizontal projection); open squares indicate inclination (vertical projection). First step is NRM, followed by $\mathrm{AF}$ steps of $2.5,5$, and $10 \mathrm{mT}$, then thermal steps from $200^{\circ}$ to $630^{\circ} \mathrm{C}$ in $50^{\circ} \mathrm{C}$ increments. Each division equals $10^{-3} \mathrm{~A} / \mathrm{m}$. See text for discussion of individual sample behavior.

\section{Methods}

In the summers of 2001 and 2002, we sampled the major sections of the Makah Formation and Hoko River Formation highlighted by Snavely et al. [8]. These include the following.

(1) The type section of the Makah Formation along the tidal exposures from Baada Point to Third Beach on the Makah Reservation (Figure 1(b)). This section described by Snavely et al. [8, Figure 4] is one of the most complete exposures of the lower Makah Formation and spans all the named members of the formation through about $1600 \mathrm{~m}$ of section. A total of 57 sites (each consisting of multiple samples) were taken to sample the available exposures as densely as possible.

(2) The referred section of the Makah Formation along the Hoko River and Ozette highway (Figures 1(b), 2). This section was illustrated by Snavely et al. [8, Figure
5], and appears to span about $2000 \mathrm{~m}$, although exposures are poor in many parts of the section. Eighteen sites were taken along the Hoko River, along with additional sites around Sekiu Point to cover the upper part of the section.

(3) The type section of the Hoko River Formation, also along Ozette Highway and the Hoko River, just to the south of the previous section (Figure 2). This section was illustrated by Snavely et al. [24, Figure 10]. Due to poor exposures, only 5 sites could be taken spanning $1600 \mathrm{~m}$ of section.

(4) A third section of Makah Formation was taken along the low-tide exposures between the mouth of the Sekiu River and Shipwreck Point, which samples mostly the Jansen Creek Member and is the source of most of the recent discoveries of marine mammals from the Makah Formation (Figure 1(b)). 


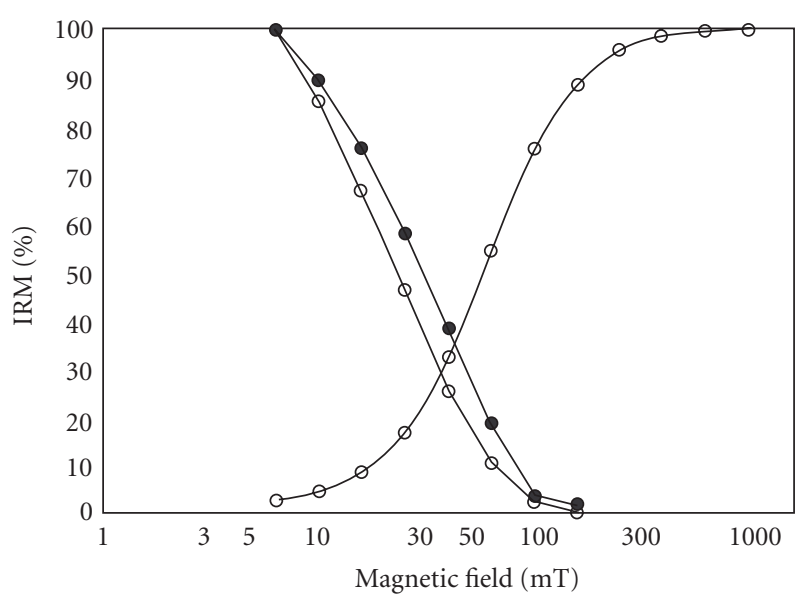

FIGURE 4: IRM acquisition (ascending curve on right) and LowrieFuller test (two descending AF demagnetization curves on left) of a representative powdered sample. Open circles = IRM; solid circles = ARM. In all samples, the IRM saturates by $300 \mathrm{mT}$, indicating that magnetite is a primary carrier of the remanence. The ARM is more resistant to AF demagnetization than the IRM, showing that the remanence is held largely in single-domain or pseudo-singledomain grains.

A minimum of three oriented block samples, and usually more, were taken at each site. Most of the rocks are well indurated and did not crumble, but dilute sodium silicate was used to harden samples that required it. In the laboratory, each block was then subsampled into standard cores using a drill press. Samples that were too poorly indurated were molded into disks of Zircar aluminum ceramic for analysis. The samples were then measured on a 2G Enterprises cryogenic magnetometer using an automatic sample changer at the California Institute of Technology.

Samples were measured at natural remanent magnetization (NRM) and then demagnetized at alternating fields (AF) 2.5, 5.0, 7.5, and 10 millitesla ( $\mathrm{mT}$ ) to assess the response by low-coercivity magnetic phases. Each sample was then thermally demagnetized at multiple steps $\left(200-630^{\circ} \mathrm{C}\right.$ in $50^{\circ} \mathrm{C}$ increments) to determine how much remanence persisted above the maximum laboratory unblocking temperature of magnetite and also to remove any overprints held in iron hydroxides, such as goethite.

About $0.1 \mathrm{~g}$ of powdered samples of selected lithologies was placed in epindorph tubes and subjected to increased isothermal remanent magnetization (IRM) to determine their IRM acquisition and saturation response. These same samples were also AF demagnetized twice, once after having acquired an IRM produced in a $100 \mathrm{mT}$ peak field, and once after having acquired an anhysteretic remanent magnetization (ARM) in a $100 \mathrm{mT}$ alternating field. These data are used for a modified Lowrie-Fuller test [52].

Demagnetization data were inspected on orthogonal demagnetization ("Zijderveld") plots and average directions of each sample were determined by the least-squares method of Kirschvink [53]. Mean directions for each site were then analyzed using Fisher [54] statistics, and classified according to the scheme of Opdyke et al. [55].

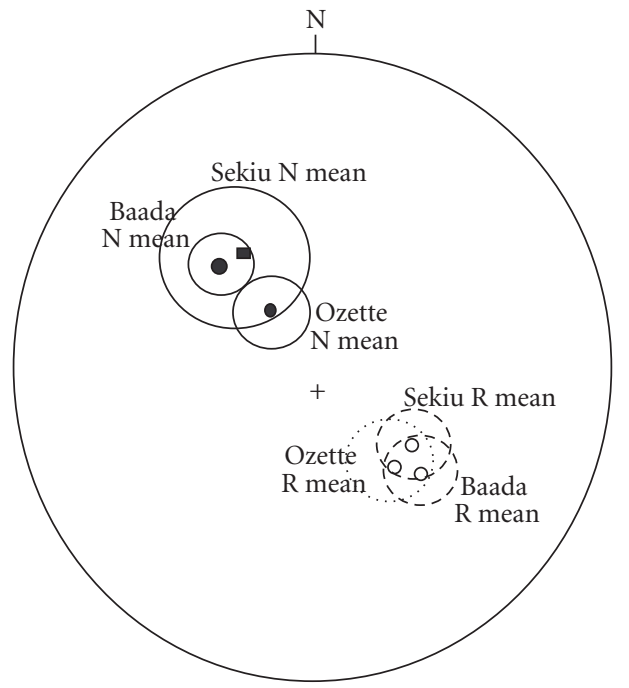

FIGURE 5: Equal area projections of estimated means directions of sites in the Makah Formation. Solid dots, rectangles, and solid circles indicate mean for normal polarity sites (lower hemisphere projection). Open dots and dashed lines indicate mean of reverse polarity samples (upper hemisphere projection). As can be seen from the plot, the directions are antipodal, suggesting that the primary remanence has been obtained and most overprinting has been removed. "Baada $\mathrm{N}$ mean" and "Baada $\mathrm{R}$ mean" refer to the means of normal and reversed sites from the Baada Point section; "Ozette N mean" and "Ozette R mean" are from the Ozette RoadHoko River section; and "Sekiu N mean;" "Sekiu R mean" are from the coastal section between Shipwreck Point and the mouth of the Sekiu River.

\section{Results}

Representative orthogonal demagnetization ("Zijderveld") plots (Figure 3) demonstrate that the vast majority of the samples (Figures 3(a)-3(c)) show a single, southeast, and up (reverse polarity, rotated almost $45^{\circ}$ counterclockwise) component that was apparent at NRM and demagnetized steadily to the origin. This component typically has a high coercivity, suggesting that chemical remanence is held in goethite or hematite, which was apparently unblocked during thermal demagnetization. However, these samples were completely unblocked by the maximum unblocking temperature of magnetite $\left(580^{\circ} \mathrm{C}\right)$, suggesting that most of the remanence is held in magnetite, not hematite. Some samples have a slight overprint to the southwest (Figure 3(d)), which were removed by the $200^{\circ} \mathrm{C}$ thermal step and revealed a southeast component that decayed to the origin by $580^{\circ} \mathrm{C}$. Figure $3(\mathrm{e})$ shows a single component of remanence pointed northwest and down and held in magnetite with high-coercivity overprints that were removed in the first thermal step; it is antipodal to the reversed samples, and it is interpreted as a normal magnetization with a counterclockwise rotation. Some samples (Figure 3(f)) show a slightly different behavior. The sample originally had an overprint directed north and down that was removed by $200^{\circ} \mathrm{C}$, revealing a southeast and negative magnetization. Unlike the behavior of the 
TABle 1: Paleomagnetic data and Fisher statistics. $N=$ number of samples per site; $D=$ declination; $I=$ inclination; $K=$ precision parameter; $\alpha_{95}=$ radius of circle of $95 \%$ confidence around the estimated mean direction.

\begin{tabular}{|c|c|c|c|c|c|c|}
\hline SITE & $N$ & $D$ & $I$ & $K$ & $\alpha_{95}$ & \\
\hline \multicolumn{7}{|c|}{ Type Makah Formation, Baada Point } \\
\hline 1 & 3 & 157.3 & -67.1 & 4.7 & 64.6 & \\
\hline 2 & 2 & 308.6 & 36.4 & 13.5 & 74.4 & \\
\hline 3 & 3 & 333.4 & 44.5 & 36.9 & 20.6 & \\
\hline 4 & 4 & 309.5 & 39.3 & 11.1 & 38.9 & \\
\hline 5 & 3 & 132.6 & -54.0 & 4.6 & 65.8 & \\
\hline 6 & 3 & 134.0 & -50.7 & 5.9 & 56.3 & \\
\hline 7 & 5 & 145.3 & -25.6 & 16.0 & 31.9 & \\
\hline 8 & 3 & 148.0 & -43.0 & 4.8 & 63.6 & \\
\hline 9 & 3 & 118.7 & -27.6 & 182.6 & 9.2 & \\
\hline 10 & 3 & 118.9 & -29.0 & 109.7 & 11.8 & \\
\hline 11 & 3 & 137.1 & -29.9 & 12.9 & 35.8 & \\
\hline 12 & 3 & 131.6 & -36.4 & 9.4 & 42.8 & \\
\hline 13 & 2 & 140.0 & -17.9 & 419.6 & 3.9 & \\
\hline 14 & 4 & 161.1 & -72.9 & 12.3 & 36.8 & \\
\hline 15 & 5 & 116.6 & -24.4 & 30.2 & 22.8 & \\
\hline 16 & 3 & 124.8 & -27.9 & 29.3 & 23.2 & \\
\hline 17 & 4 & 147.9 & -20.3 & 18.8 & 29.3 & \\
\hline 18 & 3 & 128.3 & -26.0 & 60.4 & 16.0 & \\
\hline 19 & 5 & 157.5 & -40.7 & 29.8 & 23.0 & \\
\hline \multicolumn{7}{|c|}{ Baada Point type Makah Formation } \\
\hline & $(n=8)$ & 317.8 & 41.2 & 17.0 & 13.8 & \\
\hline & $(n=47)$ & 135.1 & -37.4 & 9.3 & 7.2 & \\
\hline & $(n=55)$ & 316.9 & 37.5 & 9.8 & 6.5 & $\left(\right.$ Rotation $\left.=37.7^{\circ}\right)$ \\
\hline \multicolumn{7}{|c|}{ Ozette Road-Hoko River Makah sites } \\
\hline 1 & 3 & 139.5 & -67.2 & 820.9 & 4.3 & \\
\hline 2 & 4 & 129.2 & -65.8 & 35.9 & 20.9 & \\
\hline 3 & 3 & 134.5 & -63.1 & 8.0 & 46.9 & \\
\hline 4 & 3 & 150.6 & -54.0 & 21.8 & 27.1 & \\
\hline 5 & 4 & 152.9 & -63.0 & 17.5 & 30.4 & \\
\hline 6 & 3 & 140.6 & -71.9 & 102.5 & 12.2 & \\
\hline 7 & 5 & 143.4 & -64.3 & 542.7 & 5.3 & \\
\hline 8 & 3 & 135.4 & -61.7 & 146.3 & 10.2 & \\
\hline 9 & 3 & 165.6 & -57.2 & 11.4 & 38.4 & \\
\hline 10 & 2 & 169.1 & -73.4 & 111.0 & 23.9 & \\
\hline 11 & 3 & 160.9 & -51.6 & 26.9 & 24.3 & \\
\hline 12 & 4 & 178.8 & -49.1 & 14.4 & 33.7 & \\
\hline 13 & 3 & 308.4 & 25.3 & 13.1 & 35.6 & \\
\hline 14 & 3 & 343.8 & 43.7 & 15.7 & 32.2 & \\
\hline \multicolumn{7}{|c|}{ Ozette Road Makah Formation } \\
\hline & $(n=8)$ & 329.3 & 34.0 & 11.6 & 17.0 & \\
\hline & $(n=51)$ & 149.1 & -55.5 & 13.9 & 5.5 & \\
\hline & $(n=59)$ & 329.3 & 52.6 & 12.6 & 5.5 & $\left(\right.$ Rotation $\left.=21.2^{\circ}\right)$ \\
\hline
\end{tabular}


Table 1: Continued.

\begin{tabular}{|c|c|c|c|c|c|c|}
\hline SITE & $N$ & $D$ & $I$ & K & $\alpha_{95}$ & \\
\hline \multicolumn{7}{|c|}{ Ozette Road-Hoko River Formation sites } \\
\hline 15 & 3 & 132.6 & -49.6 & 9.3 & 43.0 & \\
\hline 16 & 2 & 342.2 & 27.8 & 134.7 & 21.7 & \\
\hline 17 & 4 & 131.6 & -23.1 & 42.2 & 19.2 & \\
\hline 18 & 3 & 145.1 & -35.6 & 19.0 & 29.1 & \\
\hline 19 & 3 & 180.6 & -41.8 & 76.4 & 14.2 & \\
\hline 20 & 3 & 147.0 & -36.1 & 11.9 & 37.4 & \\
\hline \multicolumn{7}{|c|}{ Hoko River formational mean $(n=17)$} \\
\hline & & 150.0 & -37.0 & 13.1 & 10.2 & $\left(\right.$ Rotation $\left.=33.9^{\circ}\right)$ \\
\hline \multicolumn{7}{|c|}{ Upper Makah Formation, coastline east of Shipwreck Point and west of Sekiu } \\
\hline 1 & 3 & 124.5 & -34.9 & 36.5 & 20.7 & \\
\hline 2 & 3 & 148.2 & -59.4 & 13.5 & 34.9 & \\
\hline 3 & 3 & 139.0 & -48.3 & 4.4 & 67.9 & \\
\hline 4 & 2 & 122.3 & -20.4 & 26.3 & 50.9 & \\
\hline 5 & 4 & 135.5 & -50.7 & 6.1 & 54.7 & \\
\hline 6 & 3 & 137.9 & -36.5 & 31.3 & 22.4 & \\
\hline 7 & 3 & 127.8 & -32.1 & 55.2 & 16.8 & \\
\hline 8 & 3 & 120.8 & -34.9 & 195.6 & 8.8 & \\
\hline 9 & 5 & 154.1 & -26.4 & 9.5 & 42.5 & \\
\hline 10 & 3 & 137.9 & -35.6 & 20.7 & 27.8 & \\
\hline 11 & 3 & 136.3 & -49.3 & 14.8 & 33.3 & \\
\hline 12 & 4 & 153.6 & -65.3 & 8.5 & 45.2 & \\
\hline 13 & 4 & 129.2 & -35.4 & 16.9 & 31.0 & \\
\hline 14 & 3 & 142.1 & -29.0 & 8.6 & 45.1 & \\
\hline 15 & 3 & 164.7 & -57.4 & 4.6 & 66.0 & \\
\hline 16 & 3 & 136.4 & -64.3 & 54.0 & 16.9 & \\
\hline 17 & 3 & 115.2 & -61.4 & 6.1 & 55.1 & \\
\hline \multicolumn{7}{|c|}{ Shipwreck Point-Sekiu Makah mean $(n=51)$} \\
\hline & & 135.9 & -44.4 & 10.2 & 6.6 & $\left(\right.$ Rotation $\left.=40.5^{\circ}\right)$ \\
\hline \multicolumn{7}{|c|}{ Combined mean from all Makah-Hoko River sites $(n=180)$} \\
\hline & & 320.5 & 45.2 & 10.0 & 3.7 & $\left(\right.$ Rotation $\left.=31.1^{\circ}\right)$ \\
\hline
\end{tabular}

previous samples, the sample shown in Figure 3(f) has very little high-coercivity component, suggesting that most of the remanence resides in magnetite. As is apparent from these results, all these samples (after dip correction) yield a magnetization that trends southeast and up or northwest and down.

Petrographic analysis by Snavely et al. [8, page 10-11] confirmed that magnetite was present in the matrix, along with traces of goethite or hematite cement rimming some of the framework grains. This is consistent with the magnetic behavior we have observed.

IRM acquisition experiments (Figure 4) show that the samples are dominated by magnetite as the principal magnetic phase because the samples are saturated by $300 \mathrm{mT}$. The Lowrie-Fuller tests indicate that the grains in the sample are single-domain or pseudo-single-domain, as the ARM is more resistant to AF demagnetization than IRM.

Based on relatively consistent demagnetization behavior, the direction of remanence isolated between 300 to $500^{\circ} \mathrm{C}$ in most samples was determined using the least squared method of Kirschvink [53], and each site was averaged using Fisher [54] statistics. Results are shown in Table 1. The normal and reverse directions are antipodal within error estimates, so the samples pass a reversal test. The positive reversal test suggests that the magnetizations are primary, and that most overprints have been removed (Figure 5). The dips of the beds are homoclinal $\left(30-45^{\circ}\right.$ to the northeast), so a fold test is not possible. However, it is clear that this is a primary remanence because the samples pass a reversal test, and the reverse polarity directions before tilt correction 


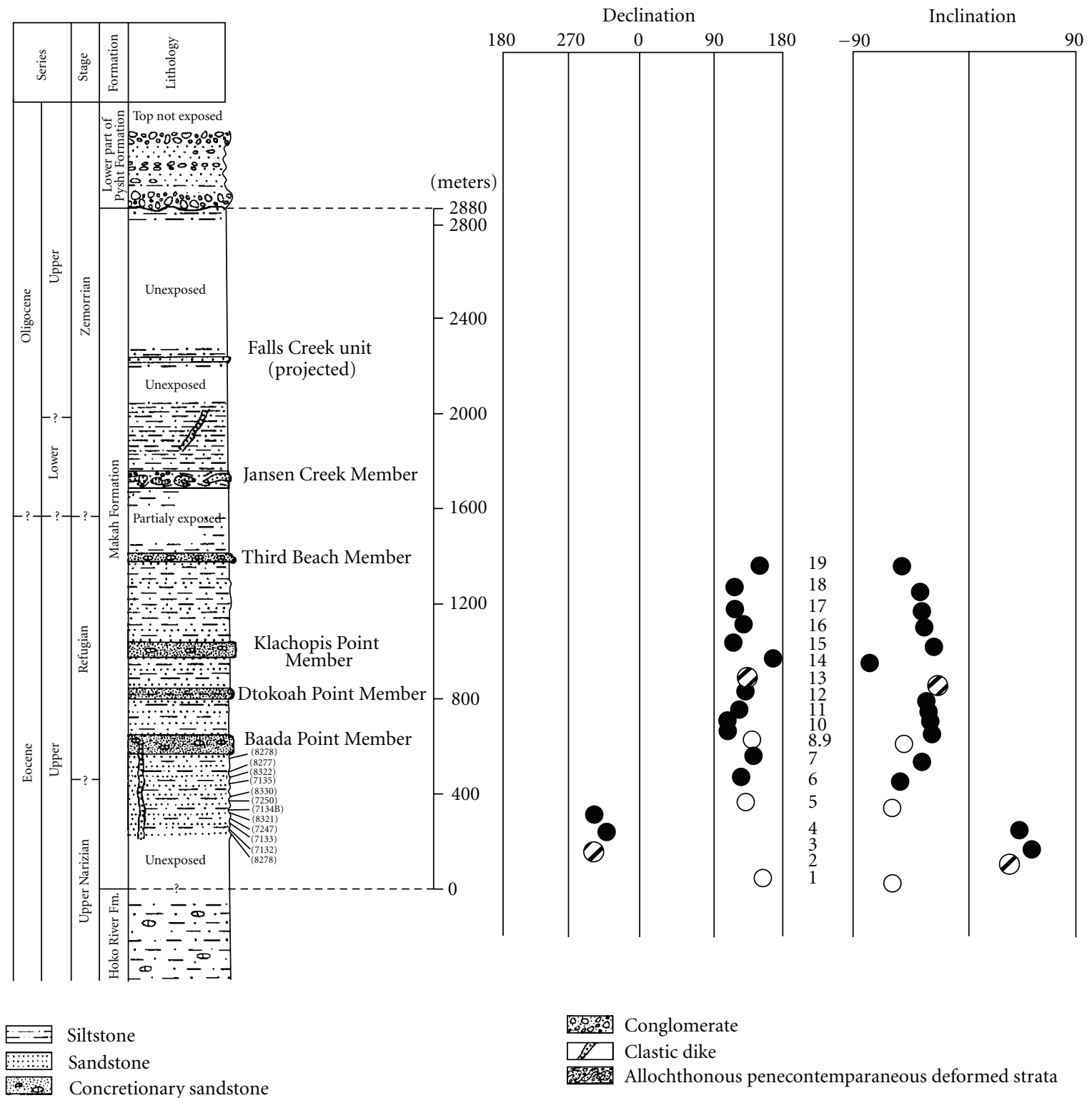

Figure 6: Magnetic stratigraphy of the type section of the Makah Formation at Baada Point. Solid circles are Class I sites of Opdyke et al. [55], which have three or more sample directions that are statistically removed from a random distribution at the $95 \%$ confidence level. Hachured circles are Class II sites of Opdyke et al. [55], which had only 2 samples that survived sampling and transport, so no statistics could be calculated. Open circles are Class III sites of Opdyke et al. [55], where two directions show a clear polarity preference, but the third sample direction is divergent. Stratigraphy modified from Snavely et al. [8, Figure 4].

are east and up (clearly not a modern normal overprint). Inverting the reverse directions and averaging all vectors, the entire section yields a mean direction of $D=320.5, I=45.2$, $k=10.0$ and $\alpha_{95}=3.7(n=162)$. This suggests about $35^{\circ}$ of counterclockwise rotation when compared to the Eocene cratonic poles $[57,58]$.

\section{Magnetostratigraphic Correlations}

Previously, the Makah Formation has been roughly interpreted to be late Eocene and early Oligocene in age, based on its benthic foraminiferans, but little precision was possible
[8]. With better age information on the benthic foraminiferal zonation $[15,16]$ and also magnetic polarity correlations calibrated by planktonic organisms such as nannofossils [17], much more precise correlations of the Makah and Hoko River Formations with the global time scale are now possible.

5.1. Makah Formation Type Section, Baada Point. The magnetic polarity stratigraphy of the type section Snavely et al. [8] (Figure 6) shows that the lowest $300 \mathrm{~m}$ of section (except for the poorly exposed base) below the Baada Point Member marker bed is a normal polarity magnetozone. The remaining sequence (from the $400 \mathrm{~m}$ level through 


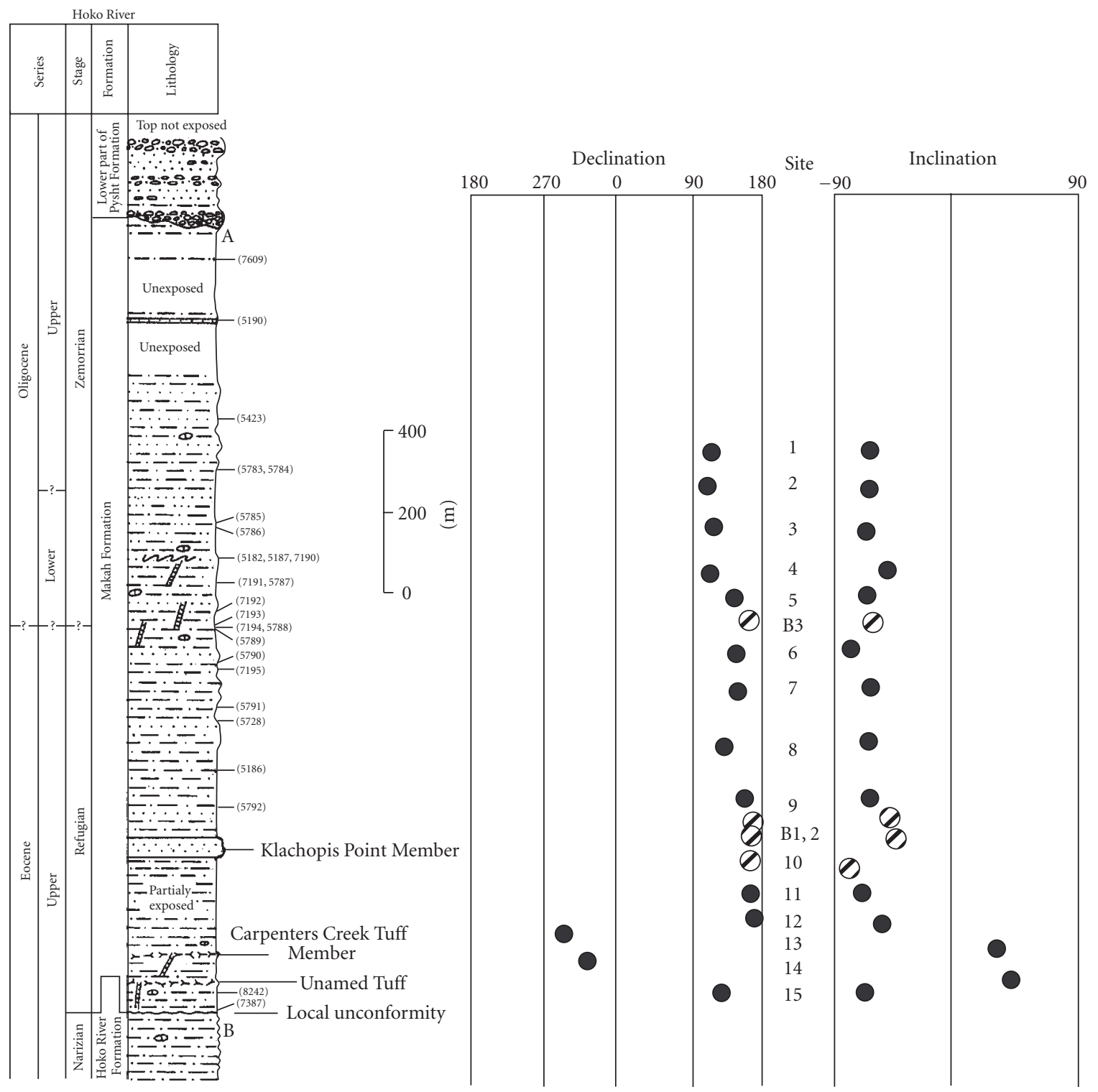

Figure 7: Magnetic stratigraphy of the Ozette Road-Hoko River section. Conventions as in Figure 6. Modified from Snavely et al. [8, Figure 5].

the Baada Point, Dtokoah Point, Klachopis Point, Third Beach members, and all the intervening shale intervals, up to $1400 \mathrm{~m}$ on the section) is entirely reverse in polarity. The section ended at the Third Beach member because the remaining part is much more poorly exposed, with long intervals that could not be sampled, so it was too patchy and incomplete to provide a intepretable record of the upper part of the Makah Formation.

5.2. Makah Formation Reference Section, Hoko River-Ozette Road. The magnetic pattern for the reference section of Snavely et al. [8] is shown in Figure 7. As in the previous section the lowermost sites are of normal polarity (sites 14 and 15 , covering the lower $100 \mathrm{~m}$ ). All of the remaining exposed parts of the formation are of reverse polarity, extending above the Klachopis Point Member marker bed and into the Jansen Creek Member.

5.3. Makah Formation Reference Section, Coast East of Shipwreck Point. The polarity pattern for this section of the upper part of the Makah Formation (including the Jansen Creek Member) is shown in Figure 8. This section is mostly deep-water siltstones and occasional thin turbidite sandstones as well as the spectacular soft-sediment folds and olistostromes described by Snavely et al. [8]. Samples were taken only from beds with uniform dip and not from deformed or slumped layers. Although the slumped layers were inspected for a possible fold test, it turned out that the folds were too poorly exposed or defined to get reliable dips, so this effort was abandoned. The Shipwreck Point section 

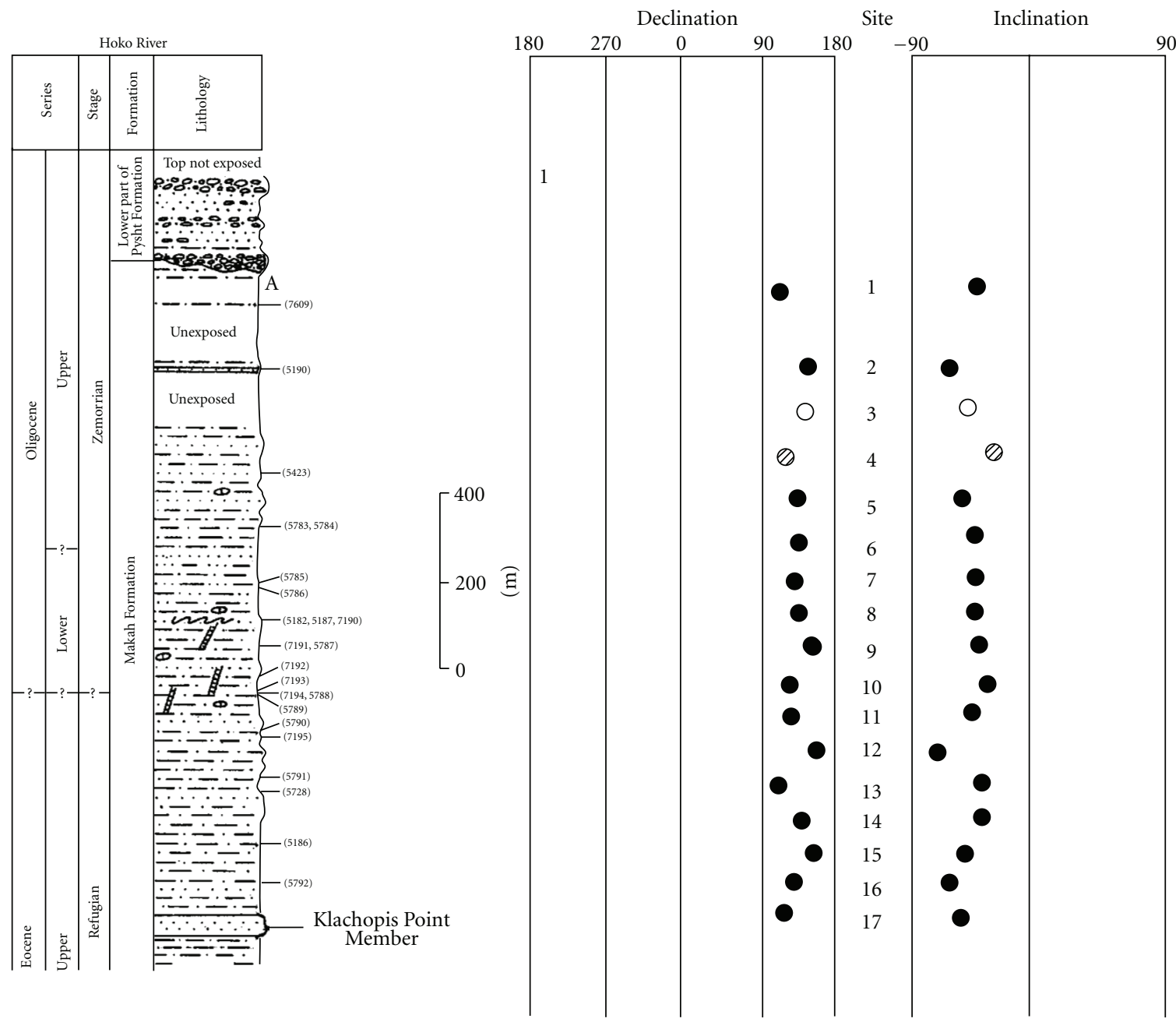

FIGURE 8: Magnetic stratigraphy of the coastal section between Shipwreck Point and the mouth of the Sekiu River. Conventions as in Figure 6.

is particularly important because it yields nearly all the fossils of marine mammals found in the Makah Formation, particularly some of the earliest known fossils of baleen and toothed whales.

The entire section is a reverse polarity magnetozone. Based on the early Zemorrian foraminifera from this unit as well as mollusks from the Liracassis rex Zone (Figure 10), the best correlation of this reverse polarity section is with Chron C12r (30.0-33.0 Ma), based on similar magnetobiostratigraphic patterns observed in the Ozette Highway section (Figure 7) as well as the pattern shown in the Lincoln Creek Formation of the southeastern Olympic Peninsula [17]. The oldest known baleen and toothed whales from this region are found near the base of the Jansen Creek Member exposures along the beaches east of Shipwreck Point [22], so these fossils are early Chron C12r in age, or earliest Oligocene (about $33 \mathrm{Ma}$ ).

5.4. Hoko River Formation Type Section, Hoko River-Ozette Highway. The best exposures of the Hoko River Formation are found along Ozette Highway and the Hoko River, just south and down-section from the Ozette Highway Makah sections described above. The section closely follows that of Snavely et al. [24, Figure 10] (Figure 9). Although this is the type section, the exposures are now extremely poor, and only five discrete sites could be taken spanning the $1600 \mathrm{~m}$ of section reported by Snavely et al. [8]. The lower four sites (spanning almost $1200 \mathrm{~m}$ of section) are reverse polarity; the uppermost site (site 15) is the only normal polarity site.

Correlation of the type section of the Hoko River Formation is less straightforward than the correlation of the Makah Formation (Figure 10). Based on the late Narizian benthic foraminiferal fauna, the long reverse magnetozone could be correlated with the relatively short Chron $\mathrm{C} 17 \mathrm{r}$ (38.0-38.2 Ma) or the much longer Chron C18r (40.0-41.2 $\mathrm{Ma})$. Because there is 1200 or more meters of reverse section in this sequence, we prefer the latter correlation. However, if the Hoko River Formation interfingers with the underlying Lyre Formation, then it is more likely that the correlation with Chron C17r is correct because the Lyre River Formation is correlated with the same interval (Prothero et al., [59]). Without planktonic microfossils or some sort of isotopic age determination, it is not possible to provide a more robust correlation on the Hoko River Formation. 


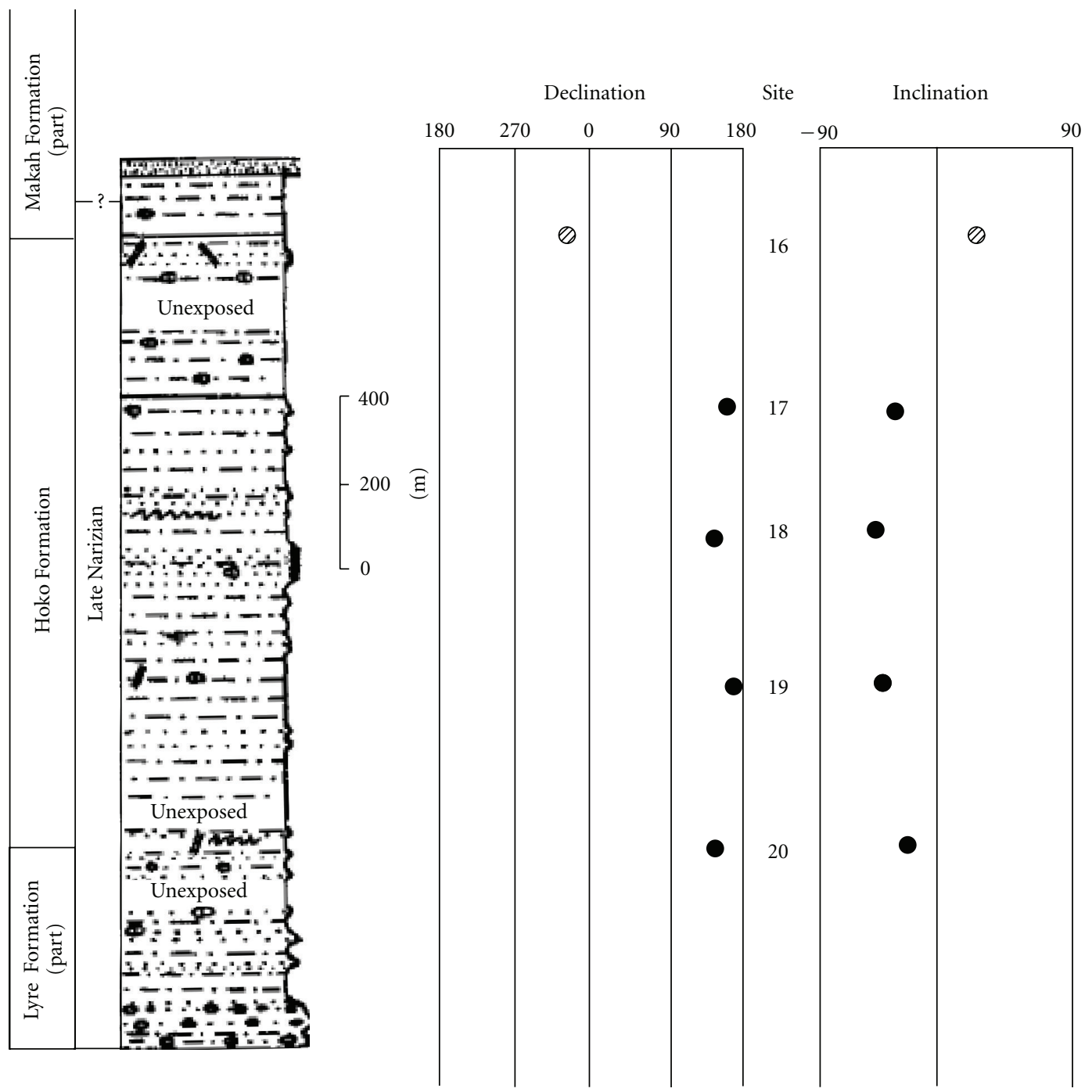

Figure 9: Magnetic stratigraphy of type section of the Hoko River Formation along Ozette Highway. Stratigraphy after Snavely et al. [24, Figure 10]. Conventions as in Figure 6.

\section{Tectonic Rotation}

The interpreted counterclockwise tectonic rotation described was unexpected because most inferred crustal rotations reported on the basis of paleomagnetic data from western Washington are clockwise in sense (Figure 11). These results include the middle Eocene Humptulips Formation in the southwestern Olympics [57, 58], the Oligocene Blakeley Formation on Bainbridge Island due east of the Olympics [60], the Oligocene-Miocene Pysht Formation [27] and Clallam Formation [61]. The underlying lower Eocene Crescent Formation, to the south of the Pysht and Clallam Formations, also shows a slight clockwise rotation [62]. However, it is consistent with several other results. Irving and Massey [63] reported a slight counterclockwise rotation for the Eocene Metchosin volcanic rocks of southern Vancouver Island, British Columbia, confirming an earlier result by Symons [64] on the Sooke Gabbro. Our 2002 sampling and analysis of the overlying Oligocene Sooke Formation
[65] also showed that the region has been rotated in a counterclockwise sense. All of the 21 Sooke Formation sites are of reverse polarity, so the characteristic remanence of this formation is clearly not an overprint. Sites from the Sooke Formation showed about $30^{\circ}$ of counterclockwise rotation with respect to Oligocene cratonic poles. Beck and Engebretson [66] reported a slight counterclockwise rotation for the Eocene volcanic rocks of the Port Townsend area in the northeastern Olympic Peninsula. Our sampling and analysis of the Eocene-Oligocene Lyre River, Quimper, and Marrowstone Formations of the Quimper Peninsula in the northeast Olympics (Prothero et al., [59]) also yielded a counterclockwise rotation. These rocks yielded both normal and reverse polarity magnetizations, which passed a reversal test and resulted in a formation mean direction of $D=308.4$, $I=51.0, k=6.7$ and $\alpha_{95}=9.5$.

The pattern of tectonic rotations (Figure 11) within the Olympic Peninsula is now much more complicated than previously thought. Except for the Pysht and Clallam 


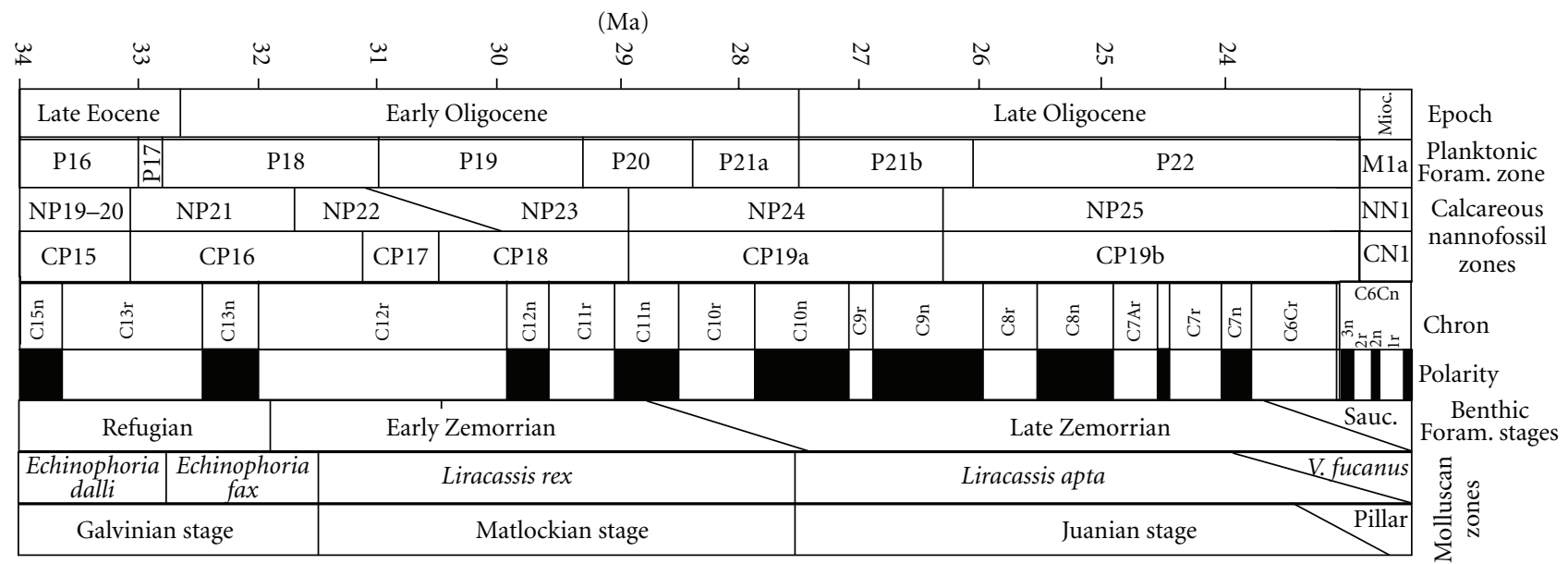

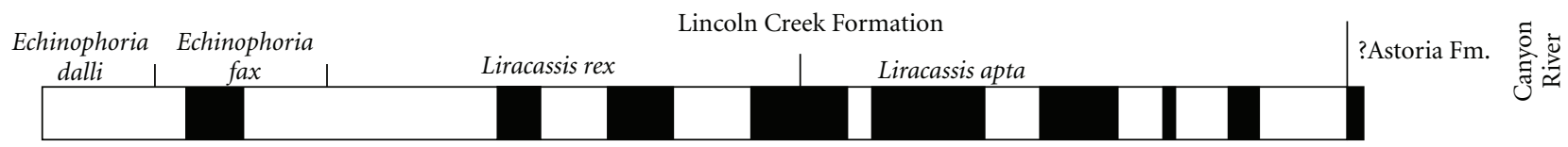

Makah Formation

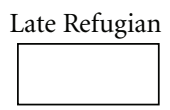

Early Zemorrian

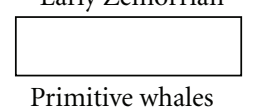

Pysht Formation

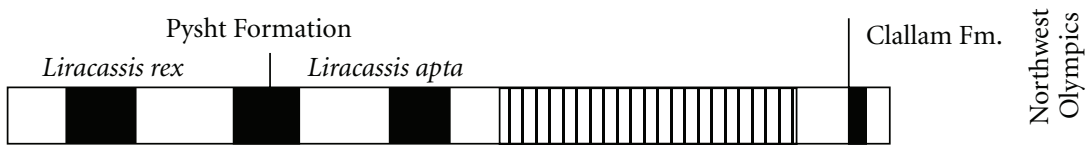

FIGURE 10: Correlation of the three Makah sections, based on the dates and age constraints discussed in the text. Lincoln Creek Formation magnetostratigraphy after Prothero and Armentrout [17]. Time scale after [15, 56].

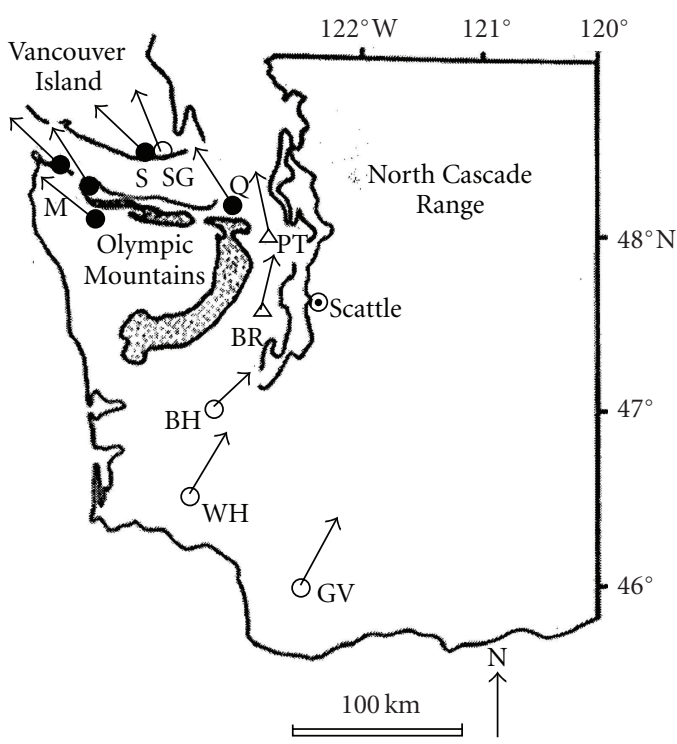

FIGURE 11: Sketch summary of the paleomagnetic data from lower Cenozoic units in the Olympic Peninsula. $\mathrm{M}=$ Makah Formation; $\mathrm{S}=$ Sooke Formation; $\mathrm{SG}=$ Sooke Gabbro; $\mathrm{Q}=$ Quimper Peninsula units; $\mathrm{PT}=$ Port Townsend basalts; $\mathrm{BR}=$ Bremerton basalts; $\mathrm{BH}=$ Black Hills; $\mathrm{WH}=$ Willapa Hills; GV = Goble volcanics (modified from [62]). results, and the data from the Crescent Formation to the south, all other rocks on the north flank of the Olympic Peninsula show a counterclockwise rotation. Beck and Engebretson [66] reported no net rotation of the Eocene Bremerton volcanic rocks, east of the Olympic Mountains. All paleomagnetic data south and southeast of the Olympic Mountains, including the Blakely Formation, the Humptulips Formation, and many earlier results on Eocene rocks south of the Olympics [67-73] show a consistent clockwise rotation. A tectonic model that might explain these results is in progress. Dr. Mark Brandon (pers. commun., 2009) currently thinks that a model in which the Olympic block pushes eastward, rotating its north flank counterclockwise and its south flank clockwise, might be able to explain most of the available data.

\section{Acknowledgments}

The authors thank J. Ludtke for help with sampling and T. LeVelle and E. Prothero for moral support. They thank J. Goedert for help sampling the Shipwreck Point exposures and for carefully reading and critiquing and early draft of the paper. In addition they thank the Tribal Council of the Makah Reservation for permission to sample on 
their land. They thank J. Kirschvink for access to the Caltech paleomagnetics lab. The authors thank A. Niem, J.W. Geissman, and three anonymous reviewers for helpful comments on the paper. Prothero was supported by NSF Grant EAR00-00174, and by a grant from the Donors of the Petroleum Research Fund, administered by the American Chemical Society, during this research.

\section{References}

[1] K. G. Miller, R. G. Fairbanks, and G. S. Mountain, “Tertiary oxygen isotope synthesis, sea level history, and continental margin erosion," Paleoceanography, vol. 2, no. 1, pp. 1-19, 1987.

[2] W. A. Berggren and D. R. Prothero, "Eocene-Oligocene climatic and biotic evolution: an overview," in EoceneOligocene Climatic and Biotic Evolution, D. R. Prothero and W. A. Berggren, Eds., pp. 1-28, Princeton University Press, Princeton, NJ, USA, 1992.

[3] D. R. Prothero, "The late Eocene-Oligocene extinctions," Annual Review of Earth \& Planetary Sciences, vol. 22, pp. 145165, 1994.

[4] D. R. Prothero, The Eocene-Oligocene Transition: Paradise Lost, Columbia University Press, New York, NY, USA, 1994.

[5] D. R. Prothero, L. C. Ivany, and E. A. Nesbitt, Eds., From Greenhouse to Icehouse: The Marine Eocene-Oligocene Transition, Columbia University Press, New York, NY, USA, 2003.

[6] K. G. Miller, J. D. Wright, and R. G. Fairbanks, "Unlocking the ice house: Oligocene-Miocene oxygen isotopes, eustasy, and margin erosion," Journal of Geophysical Research, vol. 96, no. B4, pp. 6829-6848, 1991.

[7] K. G. Miller, W. A. Berggren, J. Zhang, and A. A. PalmerJulson, "Biostratigraphy and isotope stratigraphy of upper Eocene microtektites at Site 612: how many impacts?" Palaios, vol. 6, no. 1, pp. 17-38, 1991.

[8] P. D. Snavely Jr., A. R. Niem, N. S. MacLeod, J. E. Pearl, and W. W. Rau, Makah Formation-A Deep-Marginal-Basin Sequence of Late Eocene and Oligocene Age in the Northwestern Olympic Peninsula, Washington, U.S. Geological Survey Professional Paper no. 1162-B, U.S. Geological Survey, Denver, Colo, USA, 1980.

[9] B. A. Gaskell, "Extinction patterns in Paleogene benthic foraminiferal faunas: relationship to climate and sea level," Palaios, vol. 6, no. 1, pp. 2-16, 1991.

[10] T. A. Hansen, "Extinction of late Eocene to Oligocene molluscs: relationship to shelf area, temperature changes, and impact events," Palaios, vol. 2, no. 1, pp. 69-75, 1987.

[11] T. A. Hansen, "The patterns and causes of molluscan extinctions across the Eocene/Oligocene boundary," in EoceneOligocene Climatic and Biotic Evolution, D. R. Prothero and W. A. Berggren, Eds., pp. 341-348, Princeton University Press, Princeton, NJ, USA, 1992.

[12] M. L. McKinney, B. D. Carter, K. J. McNamara, and S. K. Donovan, "Evolution of Paleogene echinoids: a global and regional view," in Eocene-Oligocene Climatic and Biotic Evolution, D. R. Prothero and W. A. Berggren, Eds., pp. 348367, Princeton University Press, Princeton, NJ, USA, 1992.

[13] N. O. Frederiksen, Sporomorph Biostratigraphy, Floral Changes, and Paleoclimatology, Eocene and Earliest Oligocene of the Eastern Gulf Coast, U.S. Geological Survey Professional Paper no. 1448, U.S. Department of the Interior, Washington, DC, USA, 1988.
[14] D. R. Prothero and R. J. Emry, Eds., The Terrestrial EoceneOligocene Transition in North America, Cambridge University Press, Cambridge, UK, 1996.

[15] D. R. Prothero, "Chronostratigraphic calibration of the Pacific Coast Cenozoic: a summary," in Magnetic Stratigraphy of the Pacific Coast Cenozoic, Pacific Section no. 91, pp. 377-394, SEPM, Tulsa, Okla, USA, 2001.

[16] K. McDougall, Paleoecological Evaluation of Late Eocene Biostratigraphic Zonations of the Pacific Coast of North America, Paleontological Society Monograph no. 2, Society of Economic Paleontologists and Mineralogists, Tulsa, Okla, USA, 1980.

[17] D. R. Prothero and J. M. Armentrout, "Magnetostratigraphic correlation of the Lincoln Creek Formation, Washington: implications for the age of the Eocene/Oligocene boundary," Geology, vol. 13, no. 3, pp. 208-211, 1985.

[18] W. W. Rau, Stratigraphy and Foraminiferal Zonation in Some of the Tertiary Rocks of Southwestern Washington, Oil and Gas Investigations Chart no. 57, U.S. Geological Survey, Denver, Colo, USA, 1958.

[19] W. W. Rau, "Stratigraphy and foraminifera of the Satsop River area, southern Olympic Peninsula, Washington," Washington Division of Mines and Geology Bulletin, vol. 53, pp. 1-66, 1966.

[20] D. R. Prothero and M. Thompson, "Magnetic stratigraphy of the type Refugian Stage (late Eocene-early Oligocene), western Santa Ynez Range, Santa Barbara County, California," in Magnetic Stratigraphy of the Pacific Coast Cenozoic, Pacific Section no. 91, pp. 119-135, SEPM, Tulsa, Okla, USA, 2001.

[21] R. E. Fordyce, "Cetacean evolution and Eocene-Oligocene oceans revisited," in From Greenhouse to Icehouse: The Marine Eocene-Oligocene Transition, D. R. Prothero, L. C. Ivany, and E. A. Nesbitt, Eds., pp. 154-171, Columbia University Press, New York, NY, USA, 2003.

[22] J. L. Goedert, R. L. Squires, and L. G. Barnes, "Paleoecology of whale-fall habitats from deep-water Oligocene rocks, Olympic Peninsula, Washington State," Palaeogeography, Palaeoclimatology, Palaeoecology, vol. 118, no. 1-2, pp. 151-158, 1995.

[23] L. G. Barnes and J. L. Goedert, "Marine vertebrate paleontology on the Olympic Peninsula," Washington Geology, vol. 24, no. 3, pp. 17-25, 1996.

[24] P. D. Snavely Jr., A. R. Niem, and J. E. Pearl, "Twin River Group (upper Eocene to lower Miocene) defined to include the Hoko River, Makah, and Pysht Formations, Clallam County, Washington," U.S. Geological Survey Bulletin, vol. 1457-A, pp. $111-119,1978$.

[25] P. D. Snavely Jr. and N. S. MacLeod, "Evolution of the Eocene continental margin of western Oregon and Washington," Geological Society of America Abstract with Programs, vol. 9, no. 7, p. $1183,1977$.

[26] N. S. MacLeod and P. D. Snavely Jr., "Volcanic and intrusive rocks of the central part of the Oregon Coast Range," in Geologic Field Trips in Northern Oregon and Southern Washington: Oregon Department of Geology and Mineral Industries Bulletin 77, pp. 47-74, Department of Geology and Mineral Industries, Portland, Ore, USA, 1973.

[27] D. R. Prothero, A. Streig, and C. Burns, "Magnetic stratigraphy and tectonic rotation of the upper Oligocene Pysht Formation, Clallam County, Washington," in Magnetic Stratigraphy of the Pacific Coast Ceonozoic, Pacific Section no. 91, pp. 226-235, SEPM, Tulsa, Okla, USA, 2001.

[28] R. L. Squires, J. L. Goedert, and S. R. Benham, "First fossil record of the pteropod Limacina from the Pacific Coast of North America," Southern California Academy of Sciences Bulletin, vol. 98, pp. 80-89, 1999. 
[29] R. M. Feldmann, "Lyreidus alseanus Rathbun from the Paleogene of Washington and Oregon," U.S.A. Annals of Carnegie Museum, vol. 58, no. 2, pp. 61-70, 1989.

[30] R. M. Feldmann, A. B. Tucker, and R. E. Berglund, "Paleobathymetry of decapod crustaceans, Washington," National Geographic Research \& Exploration, vol. 7, no. 3, pp. 352-363, 1991.

[31] C. E. Schweitzer, "Tertiary Xanthoidea (Crustacea: Decapoda: Brachyura) from the west coast of North America," Journal of Crustacean Biology, vol. 20, no. 4, pp. 715-742, 2000.

[32] C. E. Schweitzer, "Additions to the Tertiary decapod fauna of the Pacific Northwest of North America," Journal of Crustacean Biology, vol. 21, no. 2, pp. 521-537, 2001.

[33] C. E. Schweitzer and R. M. Feldmann, "First notice of the Chirostylidae (Decapoda) in the fossil record and new Tertiary Galatheidae (Decapoda) from the Americas," Bulletin of the Mizunami Fossil Museum, vol. 27, pp. 147-165, 2000.

[34] C. E. Schweitzer and R. M. Feldmann, "New Cretaceous and Tertiary decapod crustaceans from western North America," Bulletin of the Mizunami Fossil Museum, vol. 28, pp. 173-210, 2001.

[35] R. W. Wieder and R. M. Feldmann, "Palaega goedertorum, a fossil isopod (Crustacea) from late Eocene to Early Miocene rocks of Washington State," Journal of Paleontology, vol. 63, no. 1, pp. 73-80, 1989.

[36] J. L. Goedert and J. Cornish, "A preliminary report on the diversity and stratigraphic distribution of the Plotopteridae (Pelecaniformes) in Paleogene rocks of Washington State, USA," in Proceedings of the 5th Symposium of the Society of Avian Paleontology and Evolution, Z. Zhou and F. Zhang, Eds., pp. 63-76, Science Press, Beijing, China, June 2002.

[37] J. C. Underwood and C. N. Millere Jr., "Pinus buchananii, a new species based on a petrified cone from the Oligocene of Washington," American Journal of Botany, vol. 67, no. 7, pp. 1132-1135, 1980.

[38] C. N. Miller Jr., "Stems and leaves of Cunninghamiostrobus goedertii from the Oligocene of Washington," American Journal of Botany, vol. 77, no. 7, pp. 963-971, 1990.

[39] C. N. Miller Jr. and D. R. Crabtree, "A new taxodiaceous seed cone from the Oligocene of Washington," American Journal of Botany, vol. 76, no. 1, pp. 133-142, 1989.

[40] J. L. Goedert and R. L. Squires, "First Oligocene records of Calyptogena (Bivalvia: Vesicomyidae)," The Veliger, vol. 36, pp. 72-77, 1993.

[41] J. L. Goedert and K. A. Campbell, "An early Oligocene chemosynthetic community from the Makah Formation, northwestern Olympic Peninsula, Washington," The Veliger, vol. 38, pp. 22-29, 1995.

[42] R. L. Squires, "First fossil species of the chemosyntheticcommunity gastropod Provanna: localized cold-seep limestones in upper Eocene and Oligocene rocks, Washington," The Veliger, vol. 38, pp. 30-36, 1995.

[43] R. L. Squires, J. L. Goedert, and L. G. Barnes, "Whale carcasses," Nature, vol. 349, no. 6310, p. 574, 1991.

[44] S. Kiel and J. L. Goedert, "Deep-sea food bonanzas: early Cenozoic whale-fall communities resemble wood-fall rather than seep communities," Proceedings of the Royal Society B, vol. 273, no. 1601, pp. 2625-2631, 2006.

[45] S. Kiel and J. L. Goedert, "New mollusks associated with biogenic substrates in Cenozoic deep-water sediments of Washington State," Acta Palaeontologica Polonica, vol. 52, no. 1, pp. 41-52, 2007.
[46] R. D. Brown Jr. and H. D. Gower, "Twin River Formation (redefinition), northern Olympic Peninsula, Washington," American Association of Petroleum Geologists Bulletin, vol. 42, no. 10, pp. 2492-2512, 1958.

[47] M. J. Rathbun, "The fossil stalk-eyed Crustacea of the Pacific slope of North America," U.S. National Museum Bulletin, vol. 138, pp. 1-155, 1926.

[48] J. W. Durham, "Megafaunal zones of the Oligocene of northwestern Washington," University of California Publications in Geological Sciences, vol. 27, no. 5, pp. 101-211, 1944.

[49] C. E. Schweitzer and E. W. Salva, "First recognition of the Cheiragonidae (Decapoda) in the fossil record and comparison of the family with the Atelecyclidae," Journal of Crustacean Biology, vol. 20, no. 2, pp. 285-298, 2000.

[50] A. B. Tucker, "Systematics of the Raninidae (Crustacea: Decapoda: Brachyura), with accounts of three new genera and two new species," Proceedings of the Biological Society of Washington, vol. 111, no. 2, pp. 320-371, 1998.

[51] R. L. Squires, "Cephalopods from the late Eocene Hoko River Formation, northwestern Washington (USA)," Journal of Paleontology, vol. 62, no. 1, pp. 76-82, 1988.

[52] C. Pluhar, J. L. Kirschvink, and R. W. Adams, "Magnetostratigraphy and clockwise rotation of the Plio-Pleistocene Mojave River Formation, central Mojave Desert, California," San Bernardino County Museum Association Quarterly, vol. 38, no. 2, pp. 31-42, 1991.

[53] J. L. Kirschvink, "The least-squares line and plane and the analysis of palaeomagnetic data," Geophysical Journal of the Royal Astronomical Society, vol. 62, no. 3, pp. 699-718, 1980.

[54] R. A. Fisher, "Dispersion on a sphere," Proceedings of the Royal Society A, vol. 217, no. 1130, pp. 295-305, 1953.

[55] N. D. Opdyke, E. H. Lindsay, N. M. Johnson, and T. Downs, "The paleomagnetism and magnetic polarity stratigraphy of the mammal-bearing section of Anza Borrego State Park, California," Quaternary Research, vol. 7, no. 3, pp. 316-329, 1977.

[56] W. A. Berggren, D. V. Kent, C. C. Swisher III, and M.-P. Aubry, "A revised Cenozoic geochronology and chronostratigraphy," in Geochronology, Time Scales and Global Stratigraphic Correlation, Special Publication no. 54, pp. 129-212, SEPM, Tulsa, Okla, USA, 1995.

[57] J. F. Diehl, M. E Beck Jr., S. Beske-Diehl, D. Jacobson, and B. C. Hearn Jr., "Paleomagnetism of the late Cretaceous-early Tertiary north-central Montana alkalic province," Journal of Geophysical Research, vol. 88, pp. 10593-10609, 1983.

[58] D. R. Prothero, J. M. Armentrout, and P. Pearson, "Magnetic stratigraphy of the upper middle Eocene (Narizian) Humptulips Formation, Grays Harbor County, Washington," in Magnetic Stratigraphy of the Pacific Coast Ceonozoic, Pacific Section no. 91, pp. 96-106, SEPM, Tulsa, Okla, USA, 2001.

[59] D. R. Prothero, E. Draus, E. A. Nesbitt, T. M. Smiley, and C. Burns, "Paleomagnetism and tectonic rotation of the EoceneOligocene rocks of the Quimper Peninsula, northeastern Olympic Peninsula, Washington," Newsletters on Stratigraphy, vol. 43, no. 2, pp. 127-138, 2009.

[60] D. R. Prothero and E. A. Nesbitt, "Paleomagnetism and tectonic rotation of Restoration Point Member of the Blakeley Formation (type Blakeley Stage), Bainbridge Island, Washington, and the Pacific Coast Oligocene-Miocene boundary," New Mexico Museum of Natural History and Science Bulletin, vol. 44, pp. 315-322, 2008. 
[61] D. R. Prothero and C. Burns, "Magnetic stratigraphy of the upper Oligocene (type Pillarian stage) Clallam Formation, Clallam County, Washington," Pacific Section SEPM Special Publication, vol. 91, pp. 236-243, 2001.

[62] A. C. Warnock, R. F. Burmeister, and D. C. Engebretson, "Paleomagnetism and tectonics of the Crescent Formation, northern Olympic Mountains, Washington," Journal of Geophysical Research, vol. 98, no. B7, pp. 11729-11741, 1993.

[63] E. Irving and N. W. D. Massey, "Paleomagnetism of ocean layers 2 and 3: evidence from the Metchosin Complex, Vancouver Island," Physics of the Earth and Planetary Interiors, vol. 64, no. 2-4, pp. 247-260, 1990.

[64] D. T. A. Symons, "Paleomagnetic zones in the Oligocene East Sooke Gabbros, Vancouver Island, British Columbia," Journal of Geophysical Research, vol. 78, no. 23, pp. 5100-5109, 1973.

[65] D. R. Prothero, E. Draus, T. C. Cockburn, and E. A. Nesbitt, "Paleomagnetism and counterclockwise tectonic rotation of the Upper Oligocene Sooke Formation, southern Vancouver Island, British Columbia," Canadian Journal of Earth Sciences, vol. 45, no. 4, pp. 499-507, 2008.

[66] M. E. Beck Jr. and D. C. Engebretson, "Paleomagnetism of small basalt exposures in the west Puget Sound area, Washington, and speculations on the accretionary origin of the Olympic Mountains," Journal of Geophysical Research, vol. 87, no. B5, pp. 3755-3760, 1982.

[67] M. E. Beck Jr. and P. W. Plumley, "Paleomagnetism of intrusive rocks in the Coast Range of Oregon: microplate rotations in middle Tertiary time," Geology, vol. 8, no. 12, pp. 573-577, 1980.

[68] J. R. Magill and A. V. Cox, Tectonic Rotation of the Oregon Western Cascades, Oregon Department of Geology and Mineral Industries, Special Paper 10, Department of Geology and Mineral Industries, Portland, Ore, USA, 1980.

[69] J. R. Magill, A. V. Cox, and R. Duncan, "Tillamook volcanic series, further evidence for tectonic rotation of the Oregon Coast Range," Journal of Geophysical Research, vol. 86, no. B4, pp. 2953-2970, 1981.

[70] R. E. Wells, D. C. Engebretson, P. D. Snavely Jr., and R. S. Coe, "Cenozoic plate motions and the volcano- tectonic evolution of western Oregon and Washington (USA)," Tectonics, vol. 3, no. 2, pp. 275-294, 1984.

[71] R. E. Wells and R. S. Coe, "Paleomagnetism and geology of Eocene volcanic rocks of southwest Washington: implications for mechanisms of tectonic rotation," Journal of Geophysical Research, vol. 90, no. B2, pp. 1925-1947, 1985.

[72] R. E. Wells and P. L. Heller, "The relative contribution of accretion, shear, and extension to Cenozoic tectonic rotation in the Pacific Northwest," The Geological Society of America Bulletin, vol. 100, no. 3, pp. 325-338, 1988.

[73] R. E. Wells, "Paleomagnetic rotations and the Cenozoic tectonics of the Cascade arc, Washington, Oregon, and California," Journal of Geophysical Research, vol. 95, no. B12, pp. 19409-19417, 1990. 

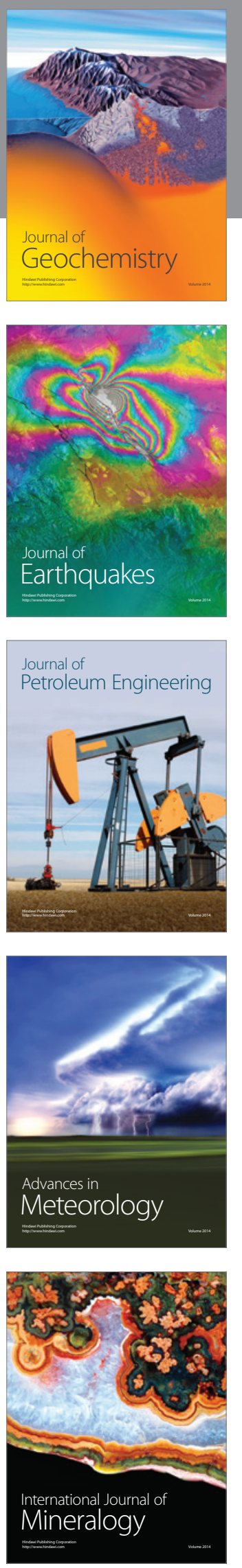
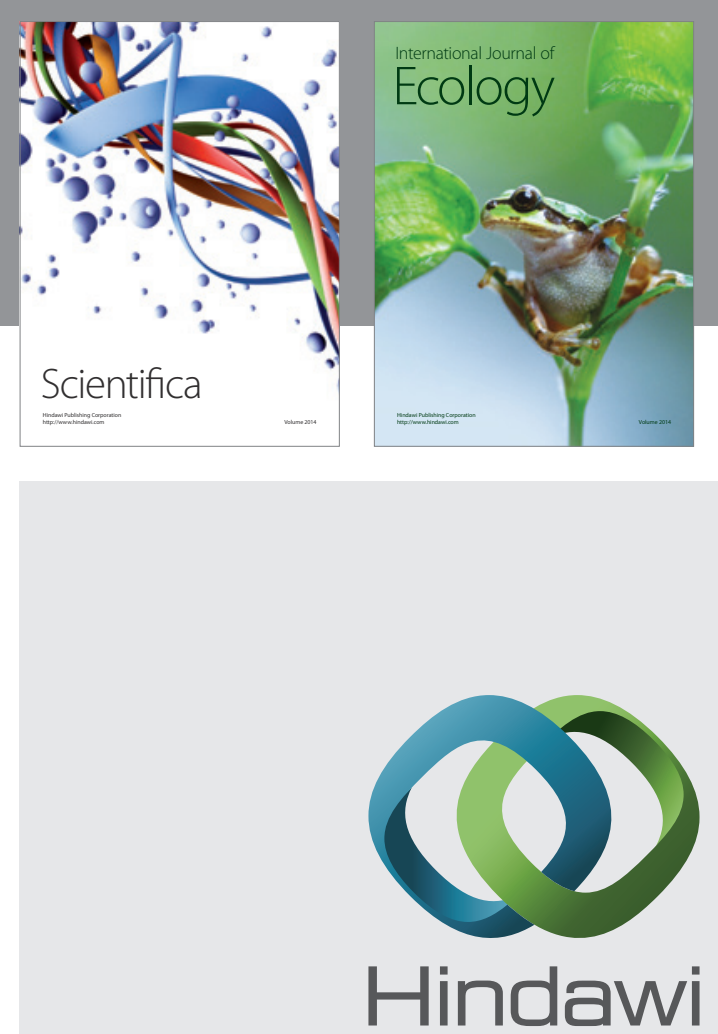

Submit your manuscripts at http://www.hindawi.com
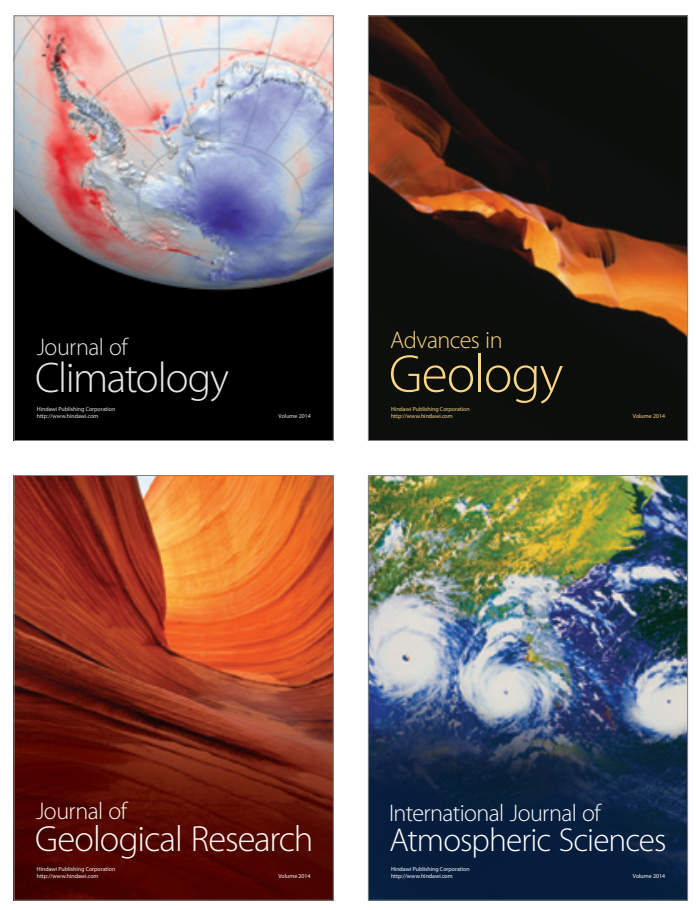
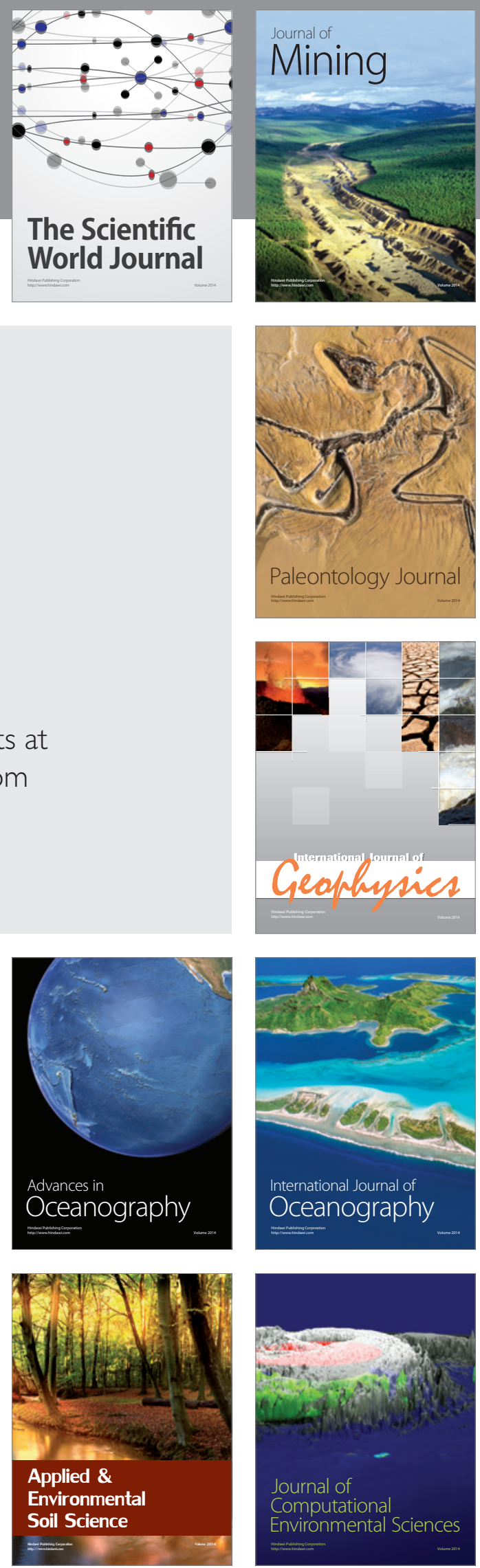